УДК 37.091.4:37.01:378.147

DOI https://doi.org/10.52726/as.pedagogy/2021.3.1.2

\author{
А. С. БАЛЬОХА \\ викладач кафедри теорії та методики дошкільної та початкової освіти, \\ Херсонський державний університет, \\ м. Херсон, Україна \\ Електронна пошта: timoshkovaalena@gmail.com \\ https://orcid.org/0000-0003-4256-5758
}

\title{
РЕАЛІЗАЦІЯ ПЕДАГОГІЧНИХ ІДЕЙ К. Д. УШИНСЬКОГО У КОНТЕКСТІ СУЧАСНИХ ОСВІТНІХ ВИМОГ ДО ПІДГОТОВКИ МАЙБУТНЬОГО ВЧИТЕЛЯ ПОЧАТКОВИХ КЛАСІВ
}

Стаття стосується сучасної проблеми підготовки майбутніх учителів початкових класів через призму дослідження педагогічного досвіду та спадщини українського та російського педагога, видатного класика педагогічної науки, автора наукових праць і підручників для початкової школи Костянтина Дмитровича Ушинського. Освітні реформи, зокрема Нова українська школа, актуалізують питання генерації нового покоління вчителів початкових класів, які будуть здатні не лише до реалізації суспільних запитів і вимог, а й формуватимуть інтелектуальний потенціал нації. Розв'язання цих завдань буде ефективним лише зі зміною освітнього процесу в закладах вищої освіти, однак нова система освіти має наслідувати принципи, розроблені науковцями-класиками. Мета статті полягає у ретроспективному дослідженні педагогічної спадщини К. Д. Ушинського, його наукових поглядів щодо підготовки майбутніх учителів початкових класів, основних принципів та ідей. За вченням К. Д. Ушинського, базовим у розвитку особистості школяра є вивчення основ науки, що розкриває перед дитиною закони природи та суспільства і певним чином впливає на розум і душу. Видані підручники для початкової школи були орієнтовані на розвиток у дітей мислення і виховання моральних якостей: любові до рідної природи і свого краю, до людей, котрі їх оточують, гуманності, доброти, працьовитості. Основним засобом у підготовці підростаючого покоління учений вважав природу, адже природні явища рано починають збуджувати розум дитини. Спостереження й вивчення рідної природи сприяє розвитку почуття патріотизму, а також естетичному вихованню. Ці ідеї актуальні у контексті реалізації природничої освітньої галузі Нової української школи, тому важливим є питання впровадження інтерактивних методів роботи зі здобувачами вищої освіти, які сприятимуть розширенню природничих знань, розвитку критичного мислення та формуванню природознавчої компетентності майбутніх учителів початкових класів. У статті розкривається практичний досвід складання пізнавальних завдань природничого змісту здобувачами вищої освіти.

Ключові слова: вища освіта, К. Д. Ушинський, майбутній вчитель початкових класів, сучасні освітні вимоги, природознавча компетентність.

Постановка проблеми. Кожен новий етап розвитку освіти безпосередньо впливає на проблему професійної підготовки вчителя. Актуальним залишається питання становлення майбутнього вчителя початкових класів, адже у руслі діджиталізації, Нової української школи, організації освітнього процесу «offline»/«online», у зв'язку 3 поширенням епідеміологічної ситуації в Україна та світі суспільство потребує нової генерації вчителів початкових класів: мобільної, конкурентоспроможної, ініціативної.

Якість підготовки вчителів початкових класів - проблема не лише сьогодення. Це питання було пріоритетним для метрів класичної педагогіки: Я.А. Коменського, Ж. Руссо, Й. Песталоцці, А. Дістервега, Д. Локка, I Гербарта
[Бальоха]. Значну увагу проблемі удосконалення педагогічної освіти вчителя було приділено вітчизняними педагогами: Х. Алчевською, М. Корфом, М. Пироговим, В. Сухомлинським, А. Макаренко [Чабан].

Теоретичні та методологічні аспекти окресленої проблеми відображені у працях відомих учених сучасності: В. Андрущенка, А. Вербицького, О. Дубасенюк, І. Зязюна, В. Кременя, О. Мороз, С. Сисоєвої, Л. Височан, О. Лінник, М. Марусинець, І. Осадченко, С. Стрілець, I. Упатової, В. Ушмарової [Бальоха].

Аналіз наукових досліджень доводить, що реформаційні процеси в освіті та підготовці майбутніх фахівців вимагають оновленого технологічного та методологічного підходу, однак незмінними залишаються ідеї та принципи 
гуманістичності, антропоцентризму та партнерства, які домінують у педагогічній спадщині К. Д. Ушинського.

Виклад основного матеріалу. В основі наукових поглядів Костянтина Дмитровича Ушинського було переконання, що якісна підготовка педагогічних кадрів для школи $є$ вирішальним фактором у покращенні освіти підростаючого покоління. Саме тому педагог значну увагу приділяв не лише навчанню та вихованню дітей, а й підготовці педагогів. Його думка, ніби справжній педагогічний фахівець має не лише добре володіти методикою, а й бути мобільним, відповідати викликам життя та часу, постійно прагнути до самовдосконалення, не втратила значущості й сьогодні. За його ініціативи відкривалися учительські семінарії, які слугували освітнім середовищем для тих, хто прагнув нести найвище звання: навчати та виховувати молоде покоління [Войтко : 35-39].

Важливим чинником виховання К. Д. Ушинський вважав вивчення основ науки, яке розкриває перед дітьми закони природи і суспільства і певним чином впливає на їх розум і душу. Створюючи підручники для початкової школи, він намагався добирати такий матеріал, котрий розвивав би у дітей мислення і виховував у них такі моральні якості, як любов до рідної природи, свого краю та до людей, які їх оточують, гуманність, доброта, працьовитість.

Виховний вплив на формування моральних рис підростаючого покоління, підкреслював учений, здійснює природа. Природні явища рано починають збуджувати розум дитини. Спілкування дітей із природою допомагає розвивати розумові здібності. Спостереження й вивчення рідної природи сприяє розвитку почуття патріотизму, а також естетичному вихованню [Мельничук].

Виходячи із власного досвіду, вчений зауважував: «Називайте мене варваром у педагогіці, але я виніс із вражень мого життя глибоке переконання, що прекрасний ландшафт має такий величезний виховний вплив на розвиток молодої душі, з яким важко змагатися впливові педагога; день, проведений дитиною серед гаїв i нив, коли iii голову опановує якийсь чарівний туман, у теплій волозі якого розкривається все їі молоде серце для того, щоб безтурботно і несвідомо вбирати в себе думки й зародки думок, які струмком ллються 3 природи, що такий день вартий багатьох тижнів, проведених на шкільній лаві» [Богуш : 45-47]. Отже, вчителі не повинні переобтяжувати дітей лише навчальними заняттями, відриваючи їх від спілкування із природою.

Універсальними формами естетичного виховання засобами природи К. Д. Ушинський уважав екскурсії у поле, гай, сад, до річки, а також уроки на природі, під час яких діти пізнають світ, красу рідної землі. Він зазначав, що логіка природи $\epsilon$ найдоступнішою і найкориснішою логікою для дітей, бо вони можуть побачити предмети та явища природи у натурі, у певному просторі та часі, перевірити свої враження про прочитане у книзі. Головне завдання вчителя Костянтин Дмитрович убачав у тому, щоб навчити дітей спостерігати за явищами й об'єктами у природі, помічати іï красу, порівнювати, зіставляти їх. У процесі спостереження розвивається логічне й образне мислення здобувачів освіти. Особливого значення він надавав сприйманню форм, кольорів, звуків, рухів у природі. Саме на цій основі здійснюється наочне навчання та розвиток сенсорної сфери дитини [Вікторенко].

К. Д. Ушинський радив педагогам насамперед вивчати природу, вікові й індивідуальні особливості дітей, щоб бути спроможним знаходити відповідні засоби виховного впливу. На його переконання, кожний учитель повинен бути не тільки вчителем, а й вихователем, щоб «вплинути» не тільки на збагачення розуму знаннями, а й на розвиток усіх розумових і моральних сил вихованців [Мельничук].

Думки педагога-демократа про підготовку вчителів викладені у таких роботах: «Проект учительської семінарії», «Три елементи школи», «Педагогічна подорож по Швейцарії», «Думка колезького радника К. Д. Ушинського про проект реорганізації Гатчинського інституту» тощо.

Костянтин Дмитрович стверджував, що вчитель не виконає свого обов'язку, якщо буде лише викладачем предмету і не буде вихователем. Знання, вважав він, не $є$ головною чеснотою викладача навчального закладу, головне щоб гімназійний викладач умів виховувати учнів своїм предметом [Войтко : 125-131].

Вплив дорослих, зокрема вчителя, на становлення особистості дитини має визначальний 
характер, причому чим менша дитина, тим більший на неї вплив вчителя. К. Д. Ушинський у більшості своїх творів неухильно доводив ідею про вирішальну роль особистості вчителя в освітньому процесі, думку, яка стала хрестоматійною істиною [Мельничук].

Він вважав, що для учителів початкових класів необхідна особлива спеціальна педагогічна підготовка та педагогічні вміння. Учитель повинен не лише вміти викладати, а також мати характер, моральність і переконання. Вчитель початкових класів має відзначатися енциклопедичними знаннями. Це мають бути знання не тільки із граматики, математики, географії та історії, а й із природничих наук, медицини, крім того, добре писати, малювати, креслити, читати чітко, виразно i, якщо можливо, навіть співати - тільки за цих умов він може повноцінно виконувати свої функції [Богуш : 67-68].

Вирішальну роль у вихованні належить фольклору, адже саме фольклор найповніше відбиває своєрідність кожного народу, зумовлену його історичним розвитком, соціальними умовами життя, географічними особливостями країни.

Загадки і прислів'я природознавчого змісту, які К. Д. Ушинський рекомендував для читання дітям, $\epsilon$ першою сходинкою для розуміння переносного значення слів і сприяють формуванню образного мислення.

У книгах К. Д. Ушинського «Рідне слово» i «Дитячий світ» природа виступає головним засобом навчання і виховання. У підручнику «Рідне слово» діти знайомляться 3 комахами, дикими та домашніми тваринами, птахами, деревами, грибами та іншими представниками природи за допомогою віршів, загадок, прислів ”ів, приказок, казок.

Зазначимо, що вимоги видатного педагога i методиста до мети, змісту, методів і засобів навчання здебільшого збігаються із сучасними вимогами освіти та відображаються у Новій українській школі, а саме інтегрованому курсі «Я досліджую світ», а тому зберігають практичну цінність та актуальність для суспільних потреб сьогодення [Типова освітня програма : 24-35].

Оскільки К. Д. Ушинський наголошував на значенні природи як засобу навчання та виховання дітей і відповідній підготовці вчителя початкових класів, можемо стверджувати, що у сьогоденній парадигмі освіти ця ідея реалізується у природ- ничій освітній галузі початкової школи та, відповідно, формуванні природознавчої компетентності майбутніх учителів початкових класів.

Принцип гуманізму як фундаментальний принцип педагогічної теорії К. Д. Ушинського передбачає впровадження інтерактивних методів, які не лише будуть мотивувати майбутніх фахівців до опанування освітніх компонент, а й розвиватимуть їх критичне мислення. Це забезпечить підвищення їх конкурентоспроможності та мобільності у сучасному швидкозмінному освітньому просторі.

Цінною практикою розвитку критичного мислення здобувачів вищої освіти, мотивацією до опанування природознавчих освітніх компонент i, як результат, формування їх природознавчої компетентності $\epsilon$ впровадження пізнавальних завдань на академічних заняттях. У нашому емпіричному дослідженні ми керувалися досвідом кандидата педагогічних наук, учителя біології К3 «Луцька гімназія № 21 імені Михайла Кравчука» Г. В. Ягенської.

Запропоновані види пізнавальних завдань здобувачі вищої освіти складали для початкової школи.

Прикладом однієї із вправ, яку майбутні вчителі початкових класів можуть реалізувати у подальшій професійній діяльності, є визначення об'єктів живої природи за головними ознаками. Головні ознаки тварин зашифровані елементами «смайлика».

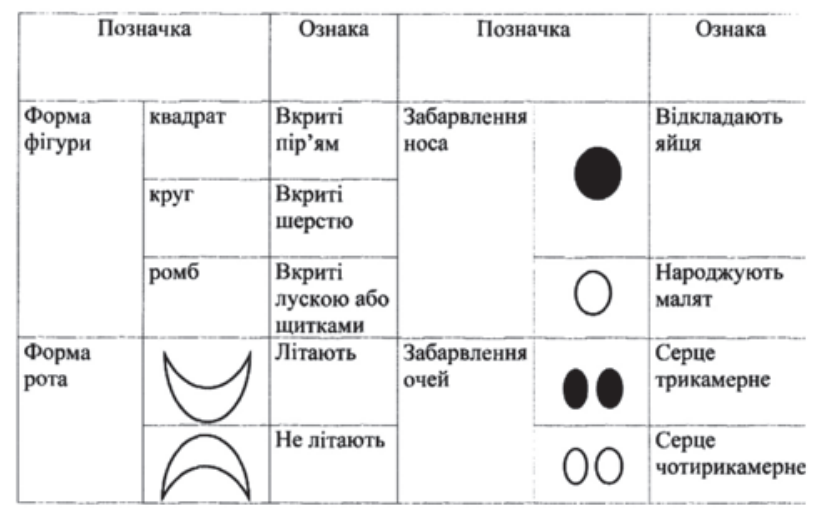

\section{Рис. 1. Зашифровані головні ознаки об'сктів живої природи}

Результатом виконання вправи $€$ не лише визначення відповідної тварини, а й складання різних смайликів, що емоційно налаштовує здобувачів освіти на освітній процес. 



Дятел

Рис. 2. Результат визначення тварин за відповідним ознаками

Варто зазначити, що такий вид вправи передбачає застосування методів і аналізу, і синтезу. Це розширює пізнавальні можливості освітнього процесу загалом і дозволяє враховувати індивідуальні можливості здобувачів освіти.

Складання запропонованої вправи мотивує майбутніх учителів початкових класів розширювати власні когнітивні знання із природничих освітніх компонент i сприяє більш ефективному формуванню їх природознавчої компетентності, що $€$ важливою складовою частиною подальшого професійного становлення.
Висновки. На завершення зазначимо, що теоретичний i практичний фонд педагогічної спадщини К. Д. Ушинського прогресивний i актуальний, заслуговує на глибоке і різнобічне вивчення, аналіз і широке використання у практиці професійної підготовки майбутніх фахівців. Педагогічні ідеї науковця, представлені у курсах загальної, дошкільної педагогіки, історії педагогіки тощо, відображені в опануванні здобувачами вищої освіти методиками освітніх компонент, у тому числі природничого спрямування, доповнюють і актуалізують сучасні підходи до формування майбутнього професіонала, розкривають внутрішні процеси його особистісного зростання, сприяють ефективному формуванню ïх природознавчої компетентності. Аналіз педагогічної спадщини педагога дає змогу не лише виокремити основні вимоги та завдання щодо професійної підготовки майбутніх учителів початкових класів, але й використати їх для удосконалення освітнього процесу, особистісного розвитку та професійного становлення майбутнього фахівця у сучасному закладі вищої освіти.

\section{ЛІТЕРАТУРА}

1. Бальоха А. С. Природознавча компетентність як складова професійної підготовки майбутнього вчителя початкових класів. Глобальні виклики педагогічної освіти в університетському просторі : матеріали III міжнародного конгресу. Одеса, 2017. С. 138-139.

2. Богуш А., Пікінер В. Педагогічна спадщина К. Д. Ушиського у вимірі сучасності : монографія. Київ : Слово, 2017. $341 \mathrm{c}$.

3. Вікторенко І. Л. Методична компетентність учителя початкових класів у навчанні природознавства молодших школярів. Теоретичний аспект. Духовність особистості: методологія, теорія і практика. 2017. № 2 (77). С. 52-61.

4. Галатюк М. Ю. Теоретичні аспекти формування навчально-пізнавальної компетентності в процесі вивчення природничих дисциплін. Наукові записки Рівненського державного гуманітарного університету. 2010. Вип. 14. C. $95-100$.

5. Мельничук С. К. Д. Ушинський про педагогічну підготовку вчителя початкових класів. Початкова школа. 2013. № 1. C. 43-44.

6. Педагогічні ідеї К. Д. Ушинського : збірник статей/відп. ред. В. І. Войтко. Київ : Вища шк., 1974. 339 с.

7. Типові освітні програми для закл. загальної середньої освіти: початкова школа: іншомовна освіта + Державний стандарт початкової освіти. Київ : ТД «ОСВІТА-ЦЕНТР+», 2018. 80 с.

8. Чабан О. В. Авторські школи як середовище реалізації інноваційного освітнього потенціалу. Педагогічні науки. 2020. Вип. 92. С. 20-27.

\section{REFERENCES}

1. Balokha, A. (2017). Pryrodoznavcha kompetentnist yak skladova profesiinoi pidhotovky maibutnoho vchytelia pochatkovykh klasiv [Natural science competence as a component of professional training of future primary school teachers], Hlobalni vyklyky pedahohichnoi osvity v universytetskomu prostori, materialy III Mizhnarodnoho konhresu [Global challenges of pedagogical education in the university space: Proceedings of the 3rd International Congress]. Odesa [in Ukrainian].

2. Bohush, A. (2017). Spadshchyna K. D. Ushyskoho u vymiri suchasnosti : monohrafiia [Pedagogical heritage of K. D. Ushisky in the dimension of modernity: monograph]. Kyiv : Slovo [in Ukrainian].

3. Viktorenko, I. (2017). Metodychna kompetentnist uchytelia pochatkovykh klasiv u navchanni pryrodoznavstva molodshykh shkoliariv [Methodical competence of primary school teachers in teaching science to primary school students]. Teoretychnyi aspekt Dukhovnist osobystosti: metodolohiia, teoriia i praktyka, 2 (77), 52-61 [in Ukrainian]. 
4. Halatiuk, M. (2010). Teoretychni aspekty formuvannia navchalno-piznavalnoi kompetentnosti v protsesi vyvchennia pryrodnychykh dystsyplin [Theoretical aspects of the formation of educational and cognitive competence in the study of natural sciences]. Naukovi zapysky Rivnenskoho derzhavnoho humanitarnoho universytetu, 14, 95-100 [in Ukrainian].

5. Melnychuk, S. (2013). K. D. Ushynskyi pro pedahohichnu pidhotovku vchytelia pochatkovykh klasiv [K. D. Ushinsky on pedagogical training of primary school teachers]. Pochatkova shkola, 1, 43-44 [in Ukrainian].

6. Voitko, V. (Ed.) (1974). Pedahohichni idei K. D. Ushynskoho [Pedagogical ideas of K. D. Ushinsky]. Kyiv: Vyshcha shkola [in Ukrainian].

7. Typovi osvitni prohramy dlia zakl. zahalnoi serednoi osvity: pochatkova shkola: inshomovna osvita + Derzhavnyi standart pochatkovoi osvity [Typical educational programs for zakl. general secondary education: primary school: foreign language education + State standard of primary education]. (2018). Kyiv: TD “OSVITA-TSENTR+", 80 p. (in Ukrainian).

8. Chaban, O. (2020). Avtorski shkoly yak seredovyshche realizatsii innovatsiinoho osvitnoho potentsialu [Author's schools as an environment for the realization of innovative educational potential]. Pedahohichni nauky, 92, 20-27 (in Ukrainian).

\author{
A. S. BALOKHA \\ Lecturer at the Department of Theory and Methods of Preschool and Primary Education, \\ Kherson State University, \\ Kherson, Ukraine \\ E-mail: timoshkovaalena@gmail.com \\ https://orcid.org/0000-0003-4256-5758
}

\title{
IMPLEMENTATION OF THE PEDAGOGICAL IDEAS OF K. USHYNSKYI IN THE CONTEXT OF MODERN EDUCATIONAL REQUIREMENTS FOR THE TRAINING OF THE FUTURE PRIMARY SCHOOL TEACHER
}

The article deals with the modern problem of training future primary school teachers through the prism of research of pedagogical experience and heritage of Ukrainian and Russian pedagogue, outstanding classic of pedagogical science, author of scientific works and textbooks for primary school Konstantin Ushynskyi. Educational reforms, in particular the New Ukrainian School, raise the issue of generation of primary school teachers who will not only be able to meet public demands and requirements, but will also create the nation's intellectual potential. Solving these problems will be effective only with a change in the educational process in the universities. However, the new education system must follow the principles developed by classical scholars. The purpose of the article is a retrospective study of the pedagogical heritage of Ushynskyi, his scientific views on the training of future primary school teachers, basic principles and ideas. According to $\mathrm{K}$. Ushynskyi, the basic in the development of the student's personality is the study of the basics of science, which reveals to the child the laws of nature and society and in some way affects their mind and soul. Published textbooks for primary school, were focused on the development of children's thinking and education of moral qualities: love for nature and their land, to the people around them, humanity, kindness, diligence. The scientist thought that the main approach in the preparation of the younger generation is nature, because natural phenomena early begin to excite the mind of the child. Observation and study of native nature contributes to the development of patriotism and also aesthetic education. These ideas are relevant in the implementation of the natural education of the New Ukrainian School. Therefore, it is important to introduce interactive methods of working with students, which will contribute to the expansion of natural knowledge, the development of critical thinking and the formation of the future primary school teachers' natural science competence. The article reveals the practical experience of compiling cognitive tasks of natural content by applicants for higher education.

Key words: higher education, K. Ushynskyi, future primary school teacher, modern educational requirements, natural science competence. 